OPEN ACCESS

Edited by:

Pierrette Gaudreau,

Centre hospitalier de l'Université de

Montréal Research Center al, Canada

Reviewed by:

Emmanuel Moyse,

University Francois Rabelais, France

${ }^{*}$ Correspondence: Isabel Beets,

isabel.beets@bio.kuleuven.be

${ }^{t}$ These authors have contributed equally to this work.

Specialty section:

This article was submitted to Neuroendocrine Science, a section of the journal Frontiers in Neuroscience

Received: 05 March 2015 Accepted: 23 March 2015

Published: 09 April 2015

Citation:

Peymen K, Watteyne J, Frooninckx L, Schoofs $L$ and Beets I (2015) Corrigendum: the FMRFamide-like peptide family in nematodes.

Front. Neurosci. 9:120

doi: 10.3389/fnins.2015.00120

\section{Corrigendum: the FMRFamide-like peptide family in nematodes}

\author{
Katleen Peymen ${ }^{\dagger}$, Jan Watteyne ${ }^{\dagger}$, Lotte Frooninckx, Liliane Schoofs and Isabel Beets * \\ Functional Genomics and Proteomics Group, Department of Biology, KU Leuven, Leuven, Belgium
}

Keywords: FMRFamide-like peptides (FLPs), nematodes, C. elegans, neuropeptide, G protein-coupled receptor, feeding behavior, reproduction

\section{A corrigendum on}

The FMRFamide-like peptide family in nematodes

by Peymen, K., Watteyne, J., Frooninckx, L., Schoofs, L., and Beets, I. (2014). Front. Endocrinol. 5:90. doi: $10.3389 /$ fendo.2014.00090

In Figure 1, NLP-1 neuropeptides (not NLP-11 as indicated in Figure 1) are released from AWC olfactory cells and activate the NPR-11 receptor. The AWC-released neuropeptide NLP-1 is stated correctly in the figure legend.

In Table 1, the activity of neuropeptides on C. elegans $\mathrm{G}$ protein-coupled receptors is indicated by an EC50 range or by an activity threshold when EC50 values could not be calculated. The activity thresholds are indicated in italic in the corrected Table 1 below.

Conflict of Interest Statement: The authors declare that the research was conducted in the absence of any commercial or financial relationships that could be construed as a potential conflict of interest.

Copyright $\odot 2015$ Peymen, Watteyne, Frooninckx, Schoofs and Beets. This is an open-access article distributed under the terms of the Creative Commons Attribution License (CC BY). The use, distribution or reproduction in other forums is permitted, provided the original author(s) or licensor are credited and that the original publication in this journal is cited, in accordance with accepted academic practice. No use, distribution or reproduction is permitted which does not comply with these terms. 


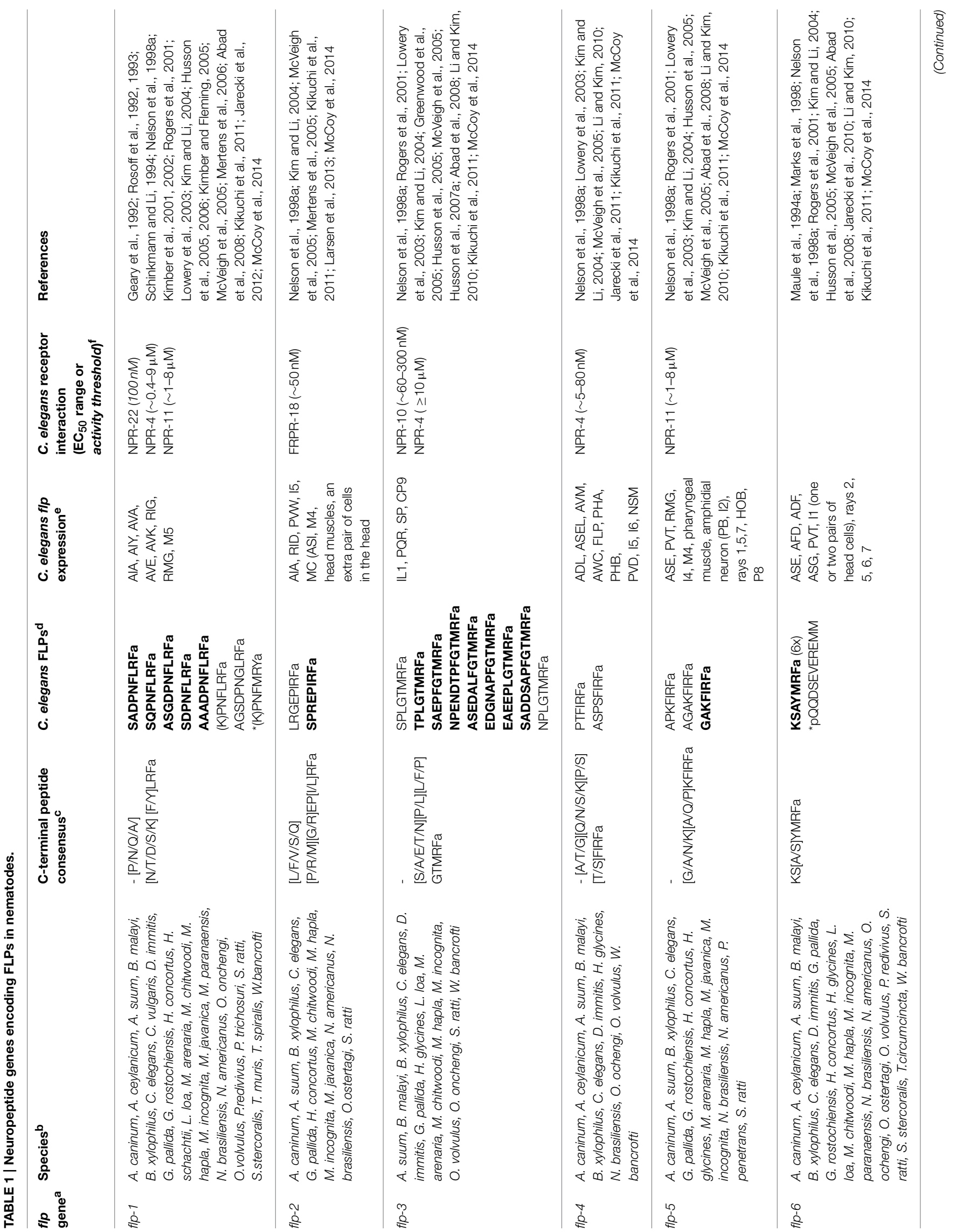




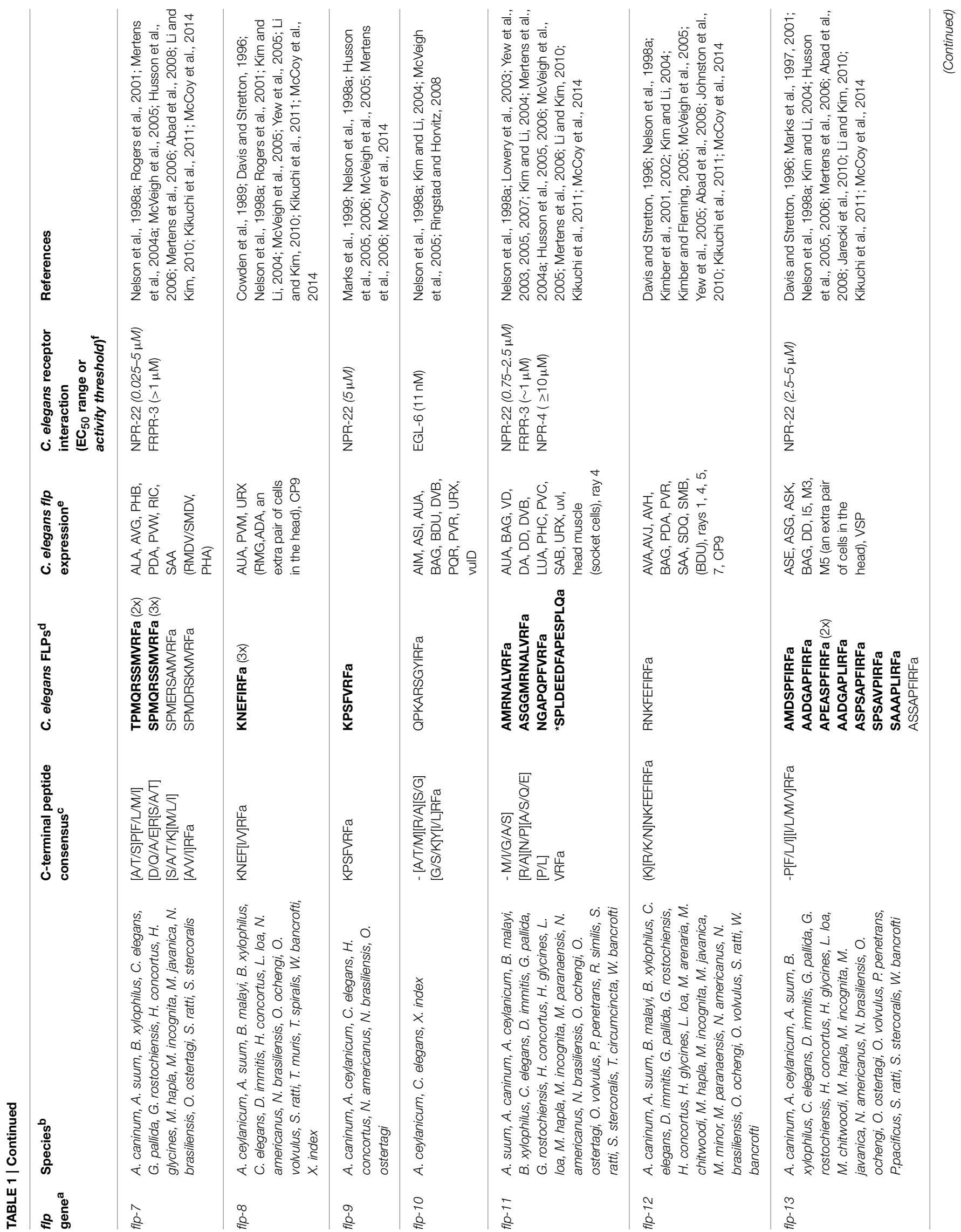




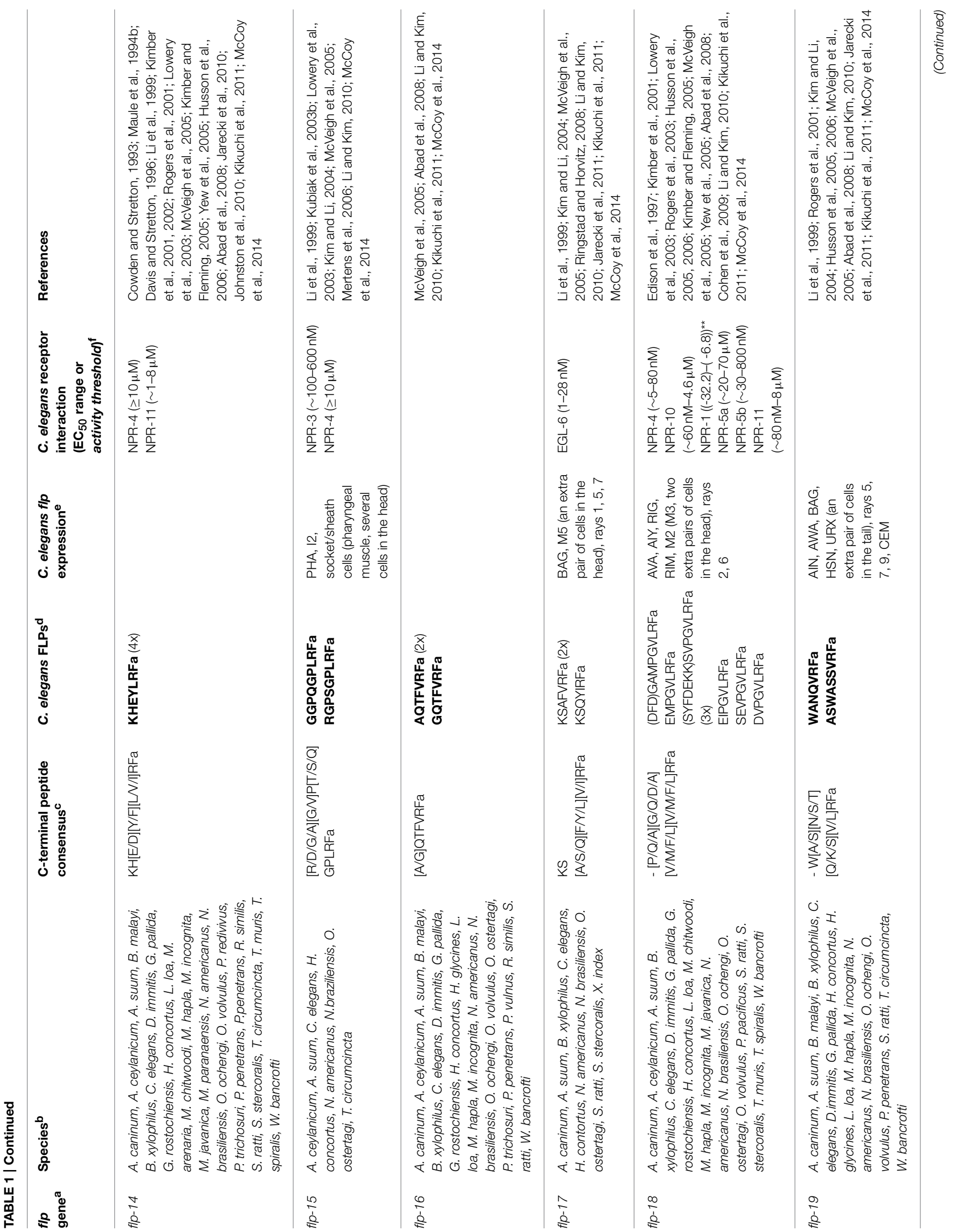




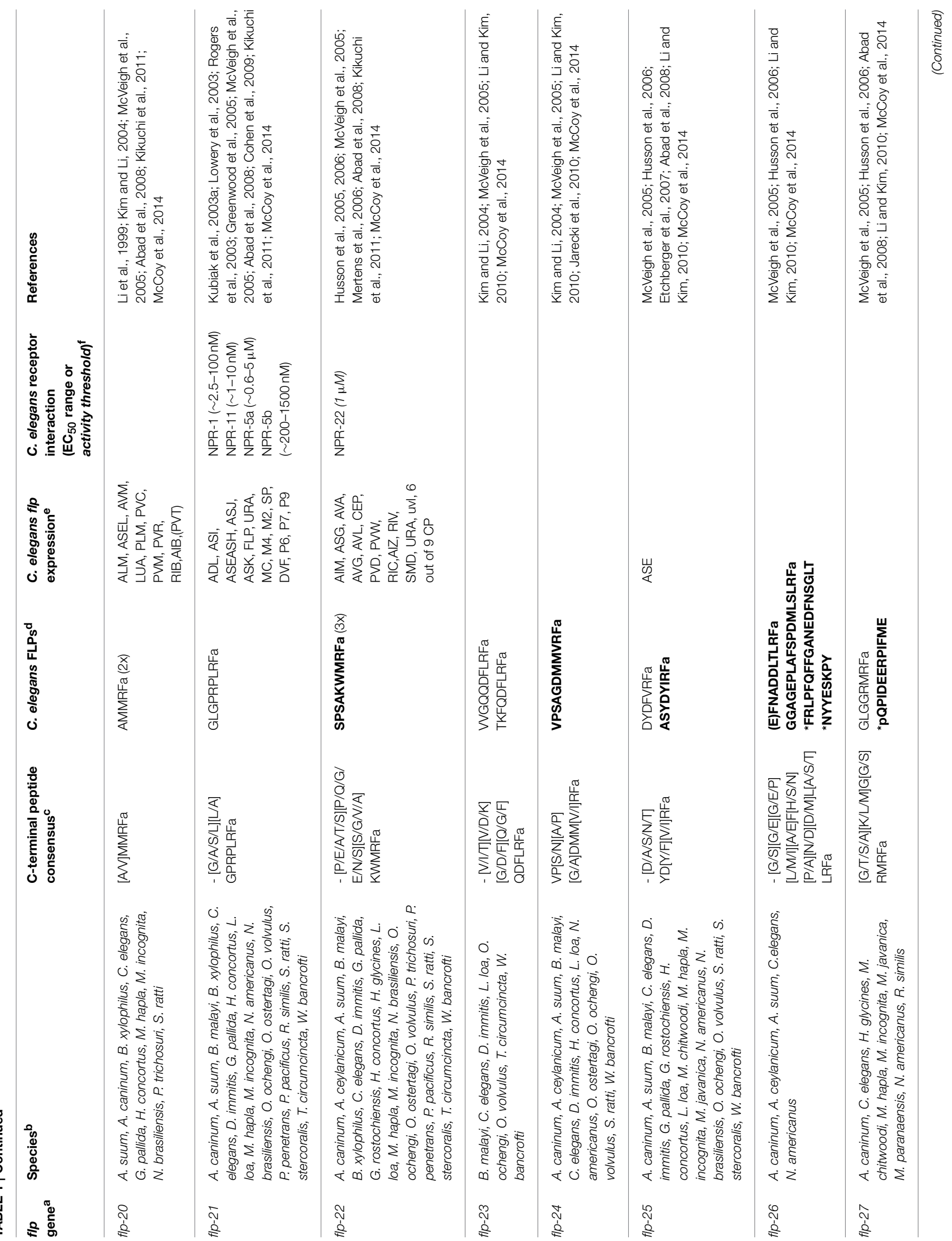




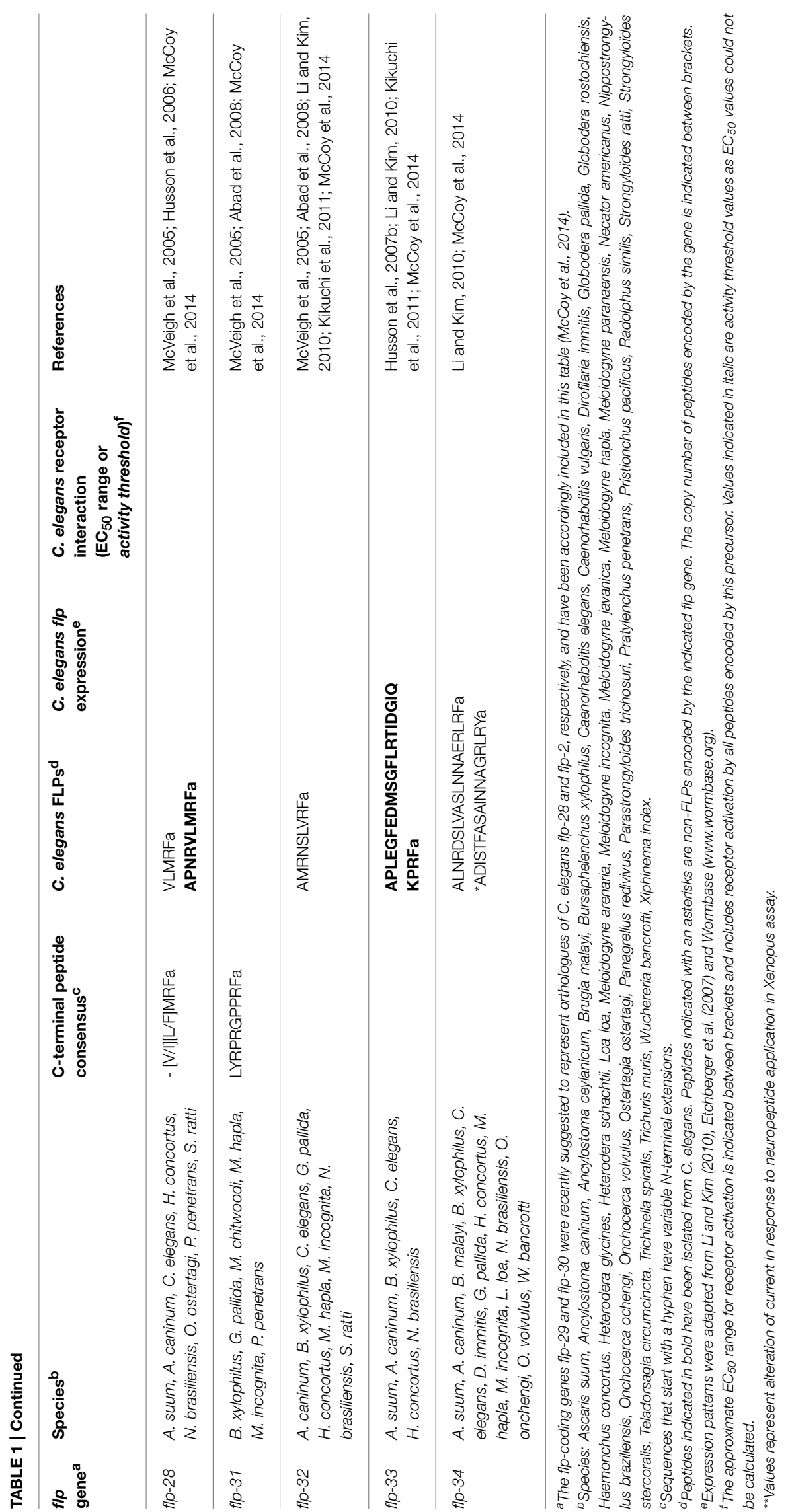

